\title{
Carbon Monoxide Oxidation on Pt-Ru Electrocatalysts Supported on High Surface Area Carbon
}

\author{
Flavio Colmati Jr., William H. Lizcano-Valbuena, Giuseppe A. Camara, Edson A. Ticianelli and \\ Ernesto R. Gonzalez*
}

Instituto de Química de São Carlos, Universidade de São Paulo, CP 780, 13560-970 São Carlos - SP, Brazil

\begin{abstract}
Este trabalho descreve a preparação e caracterização de ligas dispersas de Pt-Ru sobre carbono de alta área superficial, as quais foram avaliadas para a oxidação de CO em eletrodos de disco rotatório/camada fina porosa e para a oxidação de hidrogênio em células a combustível de eletrólito polimérico alimentadas com hidrogênio contendo $100 \mathrm{ppm}$ de $\mathrm{CO}$. Tratamentos térmicos $\left(\mathrm{H}_{2}\right.$, $300{ }^{\circ} \mathrm{C}$ ) aplicados aos catalisadores melhoram a tolerância a pequenas quantidades de $\mathrm{CO}$ e, em alguns casos, reduzem o potencial necessário para promover a oxidação de CO durante a varredura do potencial. Sob condições operacionais em uma célula a combustível na presença de CO, foi observado que os melhores resultados foram obtidos quando a liga $\mathrm{Pt}-\mathrm{Ru} / \mathrm{C}$ foi preparada por redução simultânea dos íons Pt (IV) e Ru (III), diferentemente da redução seqüencial.
\end{abstract}

This work describes the preparation and characterization of Pt-Ru alloys dispersed on high surface area carbon, which were evaluated for $\mathrm{CO}$ oxidation on thin porous coating rotating disk electrodes and for hydrogen oxidation on polymer electrolyte fuel cells fed with hydrogen containing $100 \mathrm{ppm} \mathrm{CO}$. A thermal treatment $\left(\mathrm{H}_{2}, 300{ }^{\circ} \mathrm{C}\right)$ applied to the catalysts improves the tolerance to small quantities of $\mathrm{CO}$ and, in some cases, reduces the potential necessary to promote the $\mathrm{CO}$ oxidation during a linear potential scan. Under operational conditions in a fuel cell in the presence of $\mathrm{CO}$ it was observed that the best results were obtained when the $\mathrm{Pt}-\mathrm{Ru} / \mathrm{C}$ alloy was prepared by simultaneous reduction of the ions $\mathrm{Pt}$ (IV) and $\mathrm{Ru}$ (III), as opposed to a sequential reduction.

Keywords: carbon monoxide, Pt-Ru alloys, supported catalysts, thermal treatment

\section{Introduction}

In recent years there has been a steadily growing concern with the degradation of the environment and the effect of pollutants on human health. ${ }^{1}$ High levels of pollutants are produced by internal combustion engines, particularly those running on diesel, in large urban centers. Today, the use of clean energy sources is considered an urgent necessity and, among the alternatives, fuel cells are attracting much interest. ${ }^{2}$ In particular, polymer electrolyte membrane fuel cells (PEMFC), are considered good candidates for transportation and portable applications because they are capable of delivering high power densities and can start operating at room temperature.

In spite of the efforts to develop the direct methanol fuel cell (DMFC), which has the advantage of using a liquid fuel, the most efficient low temperature fuel cells still use

* e-mail: ernesto@iqsc.sc.usp.br hydrogen as fuel. The cheapest way of producing hydrogen is by reforming fossil fuels or low molecular weight alcohols. ${ }^{3}$ This process produces $6-7 \% \mathrm{CO}$, which can be reduced to $1-2 \%$ by a shift reaction and to levels smaller than 100 ppm by partial oxidation. ${ }^{4}$ This CO adsorbs strongly on the Pt catalyst of the fuel cell electrode inhibiting the anodic reaction. The DMFC is not free of this problem, because the oxidation of methanol on $\mathrm{Pt}$ produces $\mathrm{CO}$ as an intermediate. ${ }^{5}$ The possibility of using PEMFC in transportation applications is a strong reason to search for solutions of the $\mathrm{CO}$ poisoning problem. For the DMFC a solution of this problem would allow to obtain power densities over $0.3 \mathrm{~W} \mathrm{~cm}^{-2}$, necessary to make the fuel cell powered car competitive.

When impure hydrogen is used as a fuel, several approaches have been tested to make PEMFC's run with up to $100 \mathrm{ppm} \mathrm{CO} .^{6-19}$ These involve: i) adding small amounts of oxygen (up to 5\%) to the hydrogen entering the anode, ${ }^{6-7}$ ii) performing a catalytic oxidation using Co 
oxide, ${ }^{8}$ iii) using in the anode Pt alloys with other metals like $\mathrm{Ru},{ }^{9-13} \mathrm{Sn},{ }^{14} \mathrm{Rh},{ }^{15} \mathrm{Mo},{ }^{16} \mathrm{Re},{ }^{17}$ or some noble metals like $\mathrm{Au}^{18}$ and iv) using Pt-Ru alloys and adding small amounts of hydrogen peroxide, as an oxygen carrier, to the water hydrating the membrane. ${ }^{19,20}$

Although some reports point to the Pt-Mo alloy as being the more effective, ${ }^{21} \mathrm{Pt}-\mathrm{Ru}$ alloys have been more extensively investigated. The use of Pt alloys is based on the fact that the less noble metal forms the hydrated oxides necessary to oxidize $\mathrm{CO}$ at lower potentials. Thus, the $\mathrm{CO}$ adsorbed on $\mathrm{Pt}$ is oxidized by the second metal through the so-called bifunctional mechanism: ${ }^{22}$

$\mathrm{Pt}-\mathrm{CO}+2 \mathrm{Ru}-\mathrm{OH} \rightarrow \mathrm{CO}_{2}+\mathrm{Pt}+2 \mathrm{Ru}+\mathrm{H}_{2} \mathrm{O}$

In order to understand better the oxidation of $\mathrm{CO}$ to $\mathrm{CO}_{2}$ several studies have been carried out on the adsorption of $\mathrm{CO}$ on $\mathrm{Pt}$, using techniques as FTIR ${ }^{23}$ and DEMS. ${ }^{24}$ It is observed that $\mathrm{CO}$ adsorbs on Pt in two forms: bridge and linear bonding. ${ }^{25,26}$ Morimoto et al. ${ }^{27}$ used in situ FTIR and cyclic voltammetry $(\mathrm{CV})$ to study the characteristics of the adsorption of $\mathrm{CO}$ on surfaces with different morphologies. They found that on smooth surfaces the bridge form amounts to $12 \%$, while for rough surfaces this figure increases to $29 \%$.

Ianiello et al. ${ }^{28}$ studied the oxidation of $\mathrm{CO}$ on smooth $\mathrm{Pt}$ and Pt-Ru alloys by in situ FTIR identifying the $\mathrm{OH}$ species that participate in the process. The lowest oxidation potential was found for the 50:50 Pt-Ru material. A similar result was presented by Arico et al. ${ }^{29}$ for Pt-Ru alloys supported on carbon. On smooth rotating disk electrodes (RDE) Gasteiger et al. ${ }^{9}$ proposed that the oxidation of $\mathrm{CO}$ on $\mathrm{Pt}-\mathrm{Ru}$ follows a Langmuir-Hinshelwood mechanism. Later, Schmidt et al..$^{30}$ proposed a method for the evaluation of catalysts for the oxidation of $\mathrm{H}_{2}$ and $\mathrm{CO}$ by working with Pt and Pt-Ru particles supported on carbon and covered with a Nafion ${ }^{\circledR}$ film. A kinetic study of the oxidation of $\mathrm{CO}$ was presented later by the same authors. ${ }^{31}$ Recently, it was demonstrated in this laboratory that carbon supported $\mathrm{Pt}$ and $\mathrm{Pt}-\mathrm{Ru}$ electrodes show a better performance for the oxidation of $\mathrm{H}_{2}$ containing 100 ppm $\mathrm{CO}$ when submitted to a thermal treatment. ${ }^{32}$

One of the electrochemical methods that has allowed a close study of certain electrode reactions on supported catalysts is the thin porous coating rotating disk electrode (TPC/RDE). ${ }^{33}$ This technique was used for the study of oxygen reduction, ${ }^{34-36}$ and methanol oxidation ${ }^{37}$ on carbon supported catalysts, allowing kinetic and mechanistic characterizations. In this work, the TPC/RDE technique was used to study the activity of several Pt-Ru/C electrocatalysts for the oxidation of $\mathrm{CO}$ prepared by different methods which were eventually submitted to a thermal treatment in a hydrogen atmosphere. The catalysts that showed the better performances on the TPC/RDE system were also tested in single PEMFC operating with hydrogen containing 100 ppm CO.

\section{Experimental}

Carbon supported $\mathrm{Pt}-\mathrm{Ru}$ catalysts were prepared by the following methods, using carbon powder (Vulcan XC72) pre-treated as described elsewhere: ${ }^{38}$

\section{Formic acid method $(\text { FAM })^{39}$}

This method was developed in this laboratory and uses formic acid for the reduction of $\mathrm{Pt}$ and $\mathrm{Ru}$. Developed initially as a simple method not requiring thermal treatments, it was found later that an adequate thermal treatment (here designed as T. T.) improves the performance of the catalyst for $\mathrm{H}_{2} / \mathrm{CO}$ mixtures. ${ }^{32}$ For the preparation of Pt-Ru supported alloys freshly prepared aqueous solution of $\mathrm{RuCl}_{3}$ as precursor were used, to avoid the formation of complexes $\mathrm{RuO}\left[\left(\mathrm{H}_{2} \mathrm{O}\right)_{4}\right]^{+2}$ present in aged solutions of $\mathrm{RuCl}_{3}$.

\section{Radmilovic et al. method $(R M)^{40}$}

It is similar to a method proposed earlier by Watanabe et al. (WM) ${ }^{41}$ but includes a thermal treatment in a hydrogen atmosphere at $300{ }^{\circ} \mathrm{C}$ for one hour.

In all cases the metal content with respect to carbon was $20 \%$ by weight. For the purpose of making comparisons, commercial carbon supported Pt and 50:50 Pt-Ru (E-TEK) catalysts were also used.

The composition of the prepared catalysts was examined by energy dispersive X-ray (EDX) analysis using a scanning electron microscope (DSM 960 Zeiss) with a $20 \mathrm{keV}$ electron beam and provided with a microanaliser Link Analytical QX 2000 and a detector of SiLi.

The particle sizes of the catalysts were approximately evaluated by X-ray diffraction (XRD) using a URD-6 Carl Zeiss-Jena diffractometer. The X-ray diffractograms were obtained with a low scan rate of 0.05 degree $\mathrm{s}^{-1}$ for $2 \theta$ values between 30 and $100^{\circ}$. The particle size determinations were made using the peak associated to the (220) face of the fcc platinum lattice at $2 \theta$ values between 60 and $80^{\circ}$ with a scan rate of 0.02 degree $\mathrm{s}^{-1}$. In all cases the incident wavelength $(\mathrm{K} \alpha \mathrm{Cu})$ was $1.5406 \AA$.

The electrochemical characterization of the catalyst materials was carried out using voltammetry and linear potential scans with the TPC/RDE, as described in previous 
works. ${ }^{34-36}$ The TPC/RDE was constructed using a PTFE cylinder with a cavity $0.15 \mathrm{~mm}$ deep and $0.19 \mathrm{~cm}^{2}$ area. The carbon supported catalyst was agglomerated with a $6 \%$ PTFE suspension (DuPont) and placed in the cavity. The cylinder was joined to a Pine Instrument AFMSRE rotating system with a control unit ASR2E. A reversible hydrogen electrode (RHE) was used as reference and a $2 \mathrm{~cm}^{2} \mathrm{Pt}$ foil as secondary electrode. The base electrolyte was $0.5 \mathrm{~mol} \mathrm{~L}^{-1}$ $\mathrm{H}_{2} \mathrm{SO}_{4}$ (Mallinckrodt) prepared with purified water in a MilliQ (Millipore) system. Electrochemical experiments were done with a EG\&G PAR 273 potentiostat/galvanostat coupled to a personal computer, using the software M270 (EG\&G).

Gas diffusion electrodes for single cells were prepared using a carbon cloth (Stackpole) purified by a thermal treatment at $450{ }^{\circ} \mathrm{C}$ followed by treatment with $0.5 \mathrm{~mol} \mathrm{~L}^{-1}$ $\mathrm{HNO}_{3}$ at $80{ }^{\circ} \mathrm{C}$. On the carbon cloth, a diffusion layer consisting of carbon powder (Vulcan XC-72R, Cabot) and $15 \%$ PTFE was applied first. A catalytic layer containing Nafion ${ }^{\circledR}$ and $\mathrm{Pt}$ supported alloys for the anode and Pt/C for the cathode was brushed on the diffusion layer. In all cases the metal content was $0.4 \mathrm{mg} \mathrm{cm}^{-2}$. The Nafion ${ }^{\circledR}$ content was $1.1 \mathrm{mg} \mathrm{cm}^{-2}$. Membrane and electrode assemblies were prepared with a Nafion ${ }^{\circledR} 115$ membrane (DuPont) by hot pressing the electrodes at 50 atm and $125{ }^{\circ} \mathrm{C}$. Single PEMFC experiments were carried out galvanostatically at $85^{\circ} \mathrm{C}$ with pure oxygen at $1.7 \mathrm{~atm}$ and humidified at $90{ }^{\circ} \mathrm{C}$ and with either pure hydrogen or hydrogen containing $100 \mathrm{ppm} \mathrm{CO}$, at $2 \mathrm{~atm}$ and humidified at $100{ }^{\circ} \mathrm{C}$.

\section{Results and Discussion}

\section{EDX results}

Table 1 shows the atomic composition of the different $\mathrm{Pt}-\mathrm{Ru} / \mathrm{C}$ catalysts employed in this work determined by EDX. The emitted radiation energies are $\mathrm{L} \alpha=9.441 \mathrm{kV}$ and $\mathrm{M}=2.048 \mathrm{kV}$ for $\mathrm{Pt}$ and $\mathrm{L} \alpha=2.558 \mathrm{kV}$ and $\mathrm{M}=0.461$ $\mathrm{kV}$ for $\mathrm{Ru}$. Thus, the value of the $\mathrm{L}$ energy for $\mathrm{Ru}$ is near the value of the $\mathrm{M}$ radiation for $\mathrm{Pt}$, and this may introduce errors. Table 1 shows the composition values determined. Some Pt-Ru/C catalysts, with an approximate composition 80:20 were prepared by either simultaneous or successive deposition of the metals on carbon. The amount of Ru was similar in both cases.

Previous results ${ }^{32}$ show that when the FAM method is used to prepare $\mathrm{Pt}-\mathrm{Ru} / \mathrm{C}$ catalysts it is very difficult to obtain alloy compositions with more than $30 \% \mathrm{Ru}$. On the other hand, catalysts prepared with the RM method allow the preparation of alloys with an atomic $\mathrm{Ru}$ content up to $50 \%$.
Table 1. Composition (EDX), particle size (XRD) and cell parameter $a(\mathrm{XRD})$ for the several Pt-Ru/C alloys

\begin{tabular}{ccc}
\hline $\begin{array}{c}\text { Pt-Ru atomic } \\
\text { percentage }\end{array}$ & Particle size $(\mathrm{nm})$ & Cell parameter $a(\mathrm{~nm})$ \\
\hline 100 & 2.9 & 0.39244 \\
92:08 (s) & 4.5 & 0.39103 \\
92:08 (s) T. T. & 7.8 & 0.39131 \\
84:16 (s) & 2.6 & 0.39121 \\
84:16 (s)T. T. & 2.9 & 0.39216 \\
$79: 21^{\text {a }}$ & 3.6 & 0.39188 \\
$79: 21 \mathrm{~T}^{\mathrm{T}} \mathrm{T}^{\mathrm{a}}$ & 4.7 & 0.39231 \\
$83: 17^{\mathrm{b}}$ & 6.8 & 0.39058 \\
$83: 17 \mathrm{~T} . \mathrm{T}^{\mathrm{b}}$ & 9.3 & 0.39157 \\
$75: 25(\mathrm{~s})$ & 3.4 & 0.39107 \\
$75: 25(\mathrm{~s}) \mathrm{T} . \mathrm{T}$. & 4.5 & 0.39188 \\
$50: 50 \mathrm{RM}$ & 5.0 & $0.38840^{\mathrm{c}}$ \\
50:50 E-TEK & $2.5^{\mathrm{d}}$ & - \\
\hline
\end{tabular}

T. T. = material submitted to thermal treatment.

$\mathrm{s}=$ simultaneously anchoring of $\mathrm{Pt}$ and $\mathrm{Ru}$; ${ }^{\mathrm{a}} \mathrm{Pt}$ anchored first; ${ }^{\mathrm{b}} \mathrm{Ru}$ anchored first; ${ }^{\mathrm{C}}$ From reference 40; ${ }^{\mathrm{d}}$ Unpublished TEM results.

\section{XRD results}

Figure 1 shows the diffractograms for the Pt-Ru/C catalysts prepared with the FAM. The peaks at $2 \theta=40,47$, 67 and 82 are associated to the (111), (200), (220) and (311) planes, respectively, of the fcc structure of platinum, ${ }^{42}$ or a Pt-Ru phase rich in platinum that retains the fcc structure. It was not observed any peak due to metallic ruthenium or to materials rich in $\mathrm{Ru}$ with hexagonal structure. These structures would produce a peak at $2 \theta=$ 44 , due to a reflection of the (101) plane, the most intense peak of hcp $\mathrm{Ru}$, that could indicate their presence. However, it is known that for equal quantities of $\mathrm{Pt}$ and $\mathrm{Ru}$ the intensities of $\mathrm{Ru}$ peaks are lower than those of $\mathrm{Pt}$ peaks

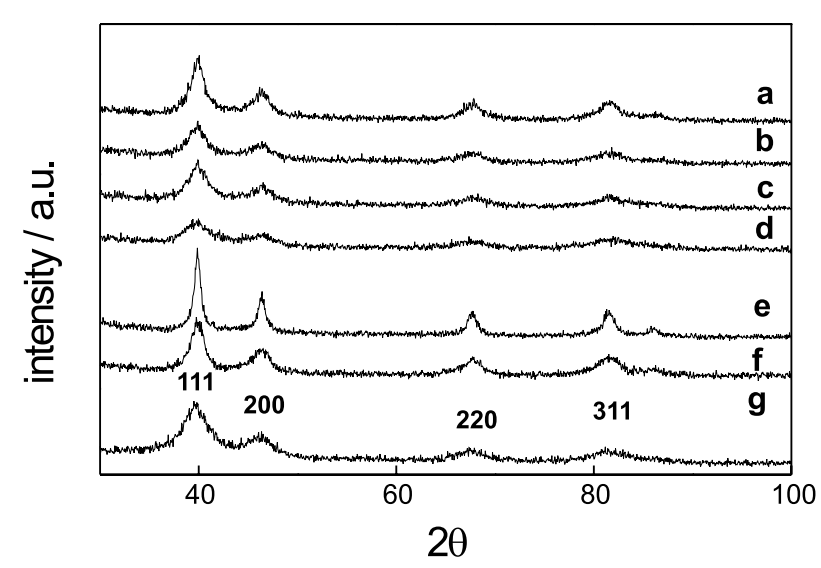

Figure 1. X-ray diffractograms for Pt-Ru/C FAM alloys with the metals anchored simultaneously. a) Pt-Ru/C 75:25 T. T.; b) Pt-Ru/C 75:25; c) Pt-Ru/C 84:16 T. T.; d) Pt-Ru/C 84:16; e) Pt-Ru/C 92:08 T. T.; f) Pt-Ru/C 92:08; g)( for comparison) Pt/C E-TEK. T.T.: thermal treatment. 
and for this reason metallic Ru may not be detected in the carbon support. Also, it has to be taken into account that $\mathrm{Ru}$ is present in smaller amount than Pt and the peaks may be superimposed because of the broadening due to small particle sizes and the strain lattice effect. ${ }^{43-44}$

When the supported alloys were treated with $\mathrm{H}_{2}$ for one hour at $300{ }^{\circ} \mathrm{C}$ it was observed that the peaks in the diffractograms become narrower, which could be due to: i) an increase in the cristallinity, ii) a lowering of the internal stress in the net of the alloy caused by a possible migration of $\mathrm{Ru}$ (as a substitution defect) or iii) an increase of the particle size. The same features are observed in the diffractograms of Figure 2, with the materials prepared by anchoring either Pt or Ru first. The profiles of the spectra were unchanged even when the catalyst powders were submitted to thermal treatment. In these cases it was expected to see the $\mathrm{Ru}$ peaks because the metals were anchored separately onto the carbon. Hovewer, no Ru peaks were observed probably due to the reasons discussed above. Figure 3 shows the diffractograms of the material prepared by the RM method and the commercial E-TEK electrocatalysts. For the RM material peaks associated to hexagonal $\mathrm{Ru}$ or species rich in $\mathrm{Ru}$ are not present, which suggests that in these materials the association between $\mathrm{Pt}$ and $\mathrm{Ru}$ is predominant. The diffractograms for the E-TEK alloys (Figure 3) are rather featureless, indicating either low crystalinity or very small particle sizes, preventing calculations of particle size or cell parameter.

\section{Mean particle size}

The mean particle size of the catalysts was determined from the X-ray diffractograms using Scherrer's equation ${ }^{45}$ and assuming that the particles are spherical. In this case, the (220) peak of fcc platinum was chosen because it

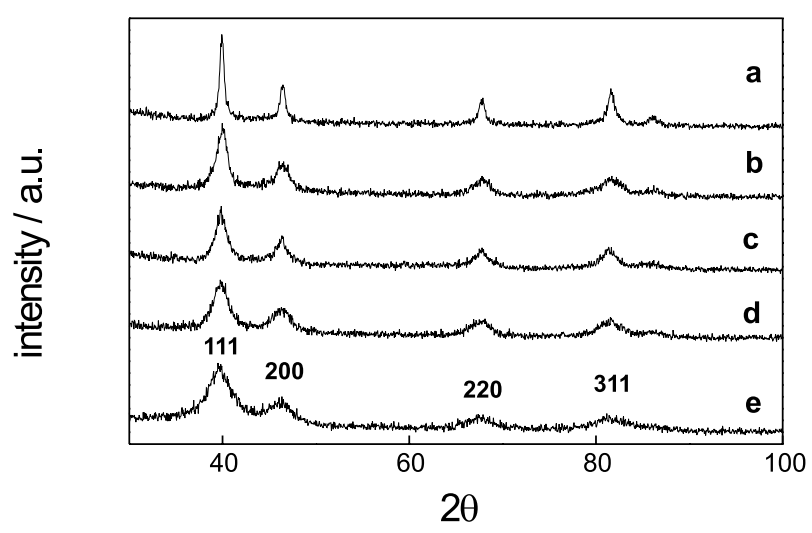

Figure 2. X-ray diffractograms for Pt-Ru/C 80:20 FAM with the metals anchored in succession. a) Ru-Pt/C T. T. b) Ru-Pt/C c) Pt-Ru/C T. T. d) $\mathrm{Pt}-\mathrm{Ru} / \mathrm{C}$ e) (for comparison) Pt/C E-TEK. T. T.: thermal treatment. appears in a region where the carbon substrate contributions can be removed, allowing a gaussian adjustment of the peaks to eliminate the background contributions. In order to obtain more precise measurements, the patterns for particle size determinations were obtained for $2 \theta$ between 60 and $80^{\circ}$ with a scan rate of 0.02 degree $\mathrm{s}^{-1}$. The mean particle sizes for all the materials used in this work are collected in Table 1. For the materials prepared with the FAM, particle sizes vary between 2.5 and $5 \mathrm{~nm}$, being comparable to those resulting from other preparation methods. The particle sizes for catalysts prepared with the $\mathrm{RM}$ are close to those published by Watanabe et al. (3-4 $\mathrm{nm})^{41}$ and Radmilovic et al. (1.9-2.3 nm). ${ }^{40}$ Table 1 also shows that in all cases the particle size increases with the thermal treatment, probably due to sintering and agglomeration of the particles.

\section{Cell parameter “ $a$ ”}

From the X-ray diffractograms, the cell parameter $a$ was also determined for the catalysts used in this work, and the values are shown in Table 1 . In all cases the values of $a$ are smaller than those found for pure $\operatorname{Pt}(0.3923 \mathrm{~nm})$, which indicates the presence of $\mathrm{Ru}$ substituting $\mathrm{Pt}$ in the lattice and leading to a smaller value of $a$. It must be noted that the value of $a$ is slightly larger for the materials submitted to thermal treatment which may indicate some segregation in the alloy. Considering the Pt-Ru/C 80:20 alloy, the lattice parameter is smaller when both metals are anchored on the carbon particles simultaneously than when $\mathrm{Pt}$ is anchored first. This is a consequence of the presence of $\mathrm{Ru}$ in the fcc lattice of $\mathrm{Pt}$, as further demonstrated by the still smaller value of $a$ when $\mathrm{Ru}$ is anchored first. When the materials are thermally treated, the values of $a$ for the catalysts obtained by simultaneous deposition and with

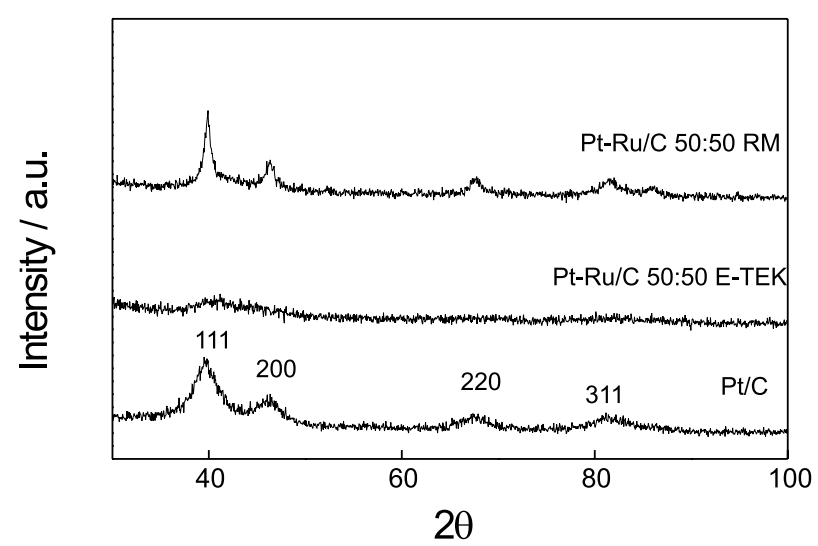

Figure 3. X-ray diffractograms for Pt-Ru/C alloys prepared by the Radmilovic method and commercial E-TEK electrocatalysts. 
the previous deposition of $\mathrm{Pt}$ increase, approaching the value for pure Pt. On the other hand, the $a$ parameter for the catalysts obtained with the initial deposition of $\mathrm{Ru}$ remains lower. In this case, a predominance of $\mathrm{Ru}$ in the lattice prevails, even after the thermal treatment.

The values of $a$ for materials prepared with the FAM are larger when compared with those of the catalysts obtained by other methods. ${ }^{40,41,46-48}$ Arc melted Pt-Ru alloys show $a=0.3904 \mathrm{~nm}$ for Pt-Ru 80:20 and $0.3864 \mathrm{~nm}$ for Pt-Ru 50:50, while this last composition has a value of 0.38965 $\mathrm{nm}$ when prepared by chemical reduction with sodium borohydride on a carbon support. ${ }^{47}$ Radmilovic et al. ${ }^{40}$ found $0.3898 \mathrm{~nm}$ for the $75: 25$ and $0.3884 \mathrm{~nm}$ for the $50: 50 \mathrm{Pt}-$ $\mathrm{Ru} / \mathrm{C}$ alloys. Thus, this method seems to favor the formation of solid solutions more than the FAM. Recently, it was reported by Takasu et al. ${ }^{48}$ that the $\mathrm{Ru}$ precursor used to produce the catalysts has an effect on the structure of the material. Thus, by using $\mathrm{RuCl}_{3}$ to produce a Pt- $\mathrm{Ru} / \mathrm{C}$ 50:50 alloy the value of $a$ was $0.391 \mathrm{~nm}$, similar to that found in this work. With $\mathrm{Ru}_{3}(\mathrm{CO})_{12}$ the values of $a$ were 0.3882 and $0.390 \mathrm{~nm}$ for Pt-Ru/C 75:25 and 50:50 respectively, and with $\mathrm{RuNO}\left(\mathrm{NO}_{3}\right)_{\mathrm{x}}$ the values were even smaller: 0.3862 and $0.3865 \mathrm{~nm}$, respectively. The possible explanation for the low incorporation of $\mathrm{Ru}$ when $\mathrm{RuCl}_{3}$ is used, is the formation of $\left[\mathrm{Ru}(\mathrm{CO})\left(\mathrm{H}_{2} \mathrm{O}\right) \mathrm{Cl}_{4}\right]^{-2}{ }^{49}$ from $\mathrm{RuCl}_{3}$ and $\mathrm{HCOOH}$ in solution when the reaction time is increased.

\section{Electrochemical characterization of the catalysts}

Cyclic voltammetry. Figure 4 shows cyclic voltammograms (CV) obtained with the TPC/RDE electrode for Pt-Ru/C 50:50 RM and Pt-Ru/C 50:50 and $\mathrm{Pt} / \mathrm{C}$ from E-TEK.

The materials containing $\mathrm{Ru}$ do not present the peaks in the hydrogen region observed for pure $\mathrm{Pt}$, which is due to the formation of $\mathrm{Ru}$ oxides at those potentials. ${ }^{50}$ Also,

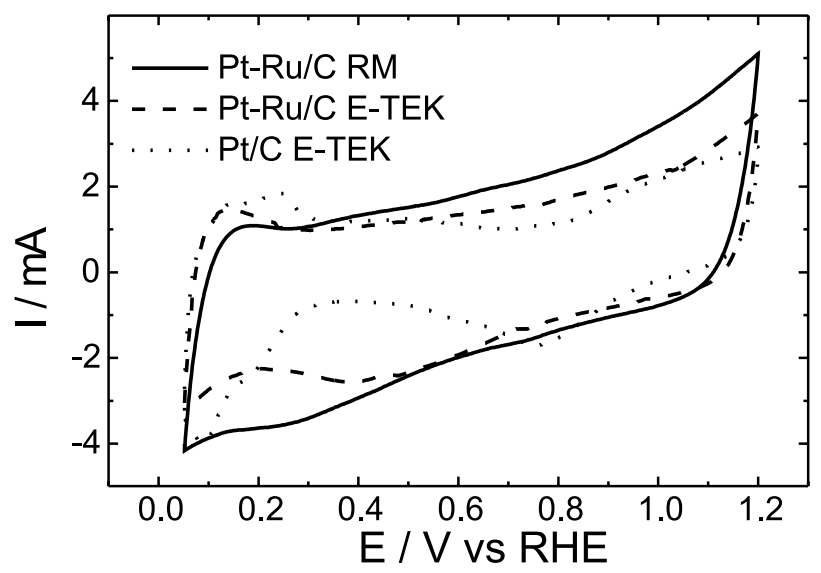

Figure 4. Cyclic voltammetries for $\mathrm{Pt}-\mathrm{Ru} / \mathrm{C}$ 50:50 prepared by the $\mathrm{RM}$ and for Pt-Ru/C 50:50 and Pt/C E-TEK. $\mathrm{v}=10 \mathrm{mV} \mathrm{s}^{-1}$. currents in the double layer are larger for these materials because of oxide formation. Some differences are apparent between the Pt-Ru/C E-TEK and the Pt-Ru/C RM. The former has a more characteristic hydrogen region and lower currents in the double layer region which is probably due to the different preparation methods. The Pt/C E-TEK material shows the typical behavior for this material in acid medium and it does not show the peak at $0.18 \mathrm{~V}$ due to the oxidation of hydrogen in the submonolayer. ${ }^{51}$

Figure 5 shows the CV's for the materials in which the metals were anchored simultaneously and separately by the FAM. Without any thermal treatment and when the metals are incorporated simultaneously (Figure 5A) the profile of the $\mathrm{CV}$ is that expected for an alloy in the sense that there is no definition of the hydrogen peaks. The profiles are slightly better defined when $\mathrm{Ru}$ was anchored first but the response is different from that of Pt/C E-TEK catalyst (Figure 5B). After the thermal treatment there are clear changes in the profiles that can be the result of: i) a reduced amount of $\mathrm{Ru}$ oxides, ii) segregation of $\mathrm{Ru}$, iii) elimination of impurities, which may increase the area of the clean active surface and iv) an increase of particle size.

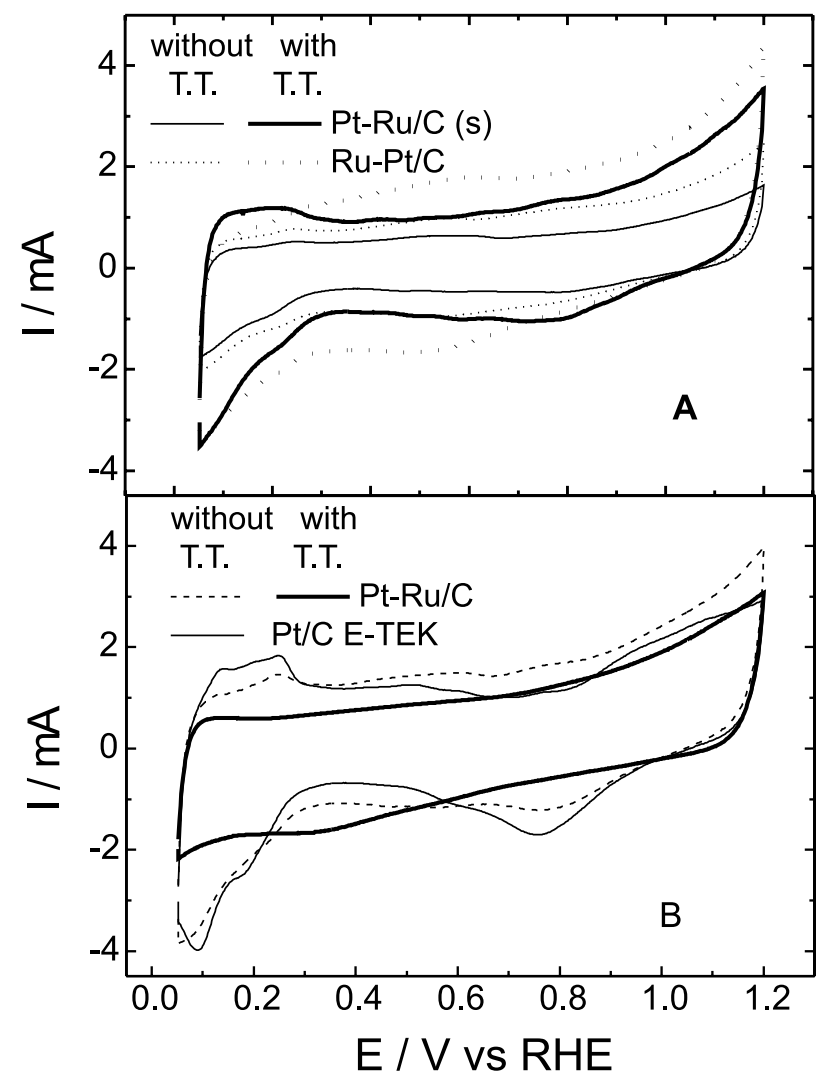

Figure 5. Cyclic voltammetries of Pt-Ru/C 80:20 alloys prepared by the FAM, with and without thermal treatment (T.T.) (A) For the two metals anchored simultaneously (s) and $\mathrm{Ru}$ anchored first (Ru-Pt/ C). (B) For the Pt anchored first $(\mathrm{Pt}-\mathrm{Ru} / \mathrm{C})$ and, for comparison, for $\mathrm{Pt} / \mathrm{C}$ E-TEK. 
Effects (i-iii) are expected to increase the current, while effect (iv) should result in a decrease.

The thermal treatment results in a marked increase in the current levels for the material in which the metals were anchored simultaneously and for the material in which $\mathrm{Ru}$ was anchored first (Figure 5A). It is probable that, in spite of the increase in particle size, effects i-iii are predominant for these materials. The opposite must be the case for the material in which Pt was anchored first (Figure 5B) because a decrease of current levels is observed as a consequence of the thermal treatment.

Linear sweep voltammetry. The dependence of the amount of $\mathrm{CO}$ adsorbed with the electrode potential was studied by linear sweep voltammetry. In order to guarantee equilibrium conditions for the $\mathrm{CO}$ adsorption process with the TPC/RDE, the electrode was rotated at $1600 \mathrm{rpm}$ for an adequate time. This was necessary because of the low solubility $\left(0.96 \times 10^{-3} \mathrm{~mol} \mathrm{~L}^{-1}\right)$ and diffusion coefficient $\left(1.8 \times 10^{-5} \mathrm{~cm}^{2} \mathrm{~s}^{-1}\right)$ of $\mathrm{CO}$ in $0.5 \mathrm{~mol} \mathrm{~L}^{-1} \mathrm{H}_{2} \mathrm{SO}_{4} \cdot{ }^{9}$ Also, before applying the linear voltage scan it was necessary to eliminate the $\mathrm{CO}$ in the solution and in the pores of the TPC/RDE. This was done by bubbling $\mathrm{N}_{2}$ with the electrode rotating at $1600 \mathrm{rpm}$ until the response to the linear voltage scan was the same with and without rotation. Figure 6 shows a linear sweep voltammogram on Pt/C E-TEK for the oxidation of $\mathrm{CO}$ previously adsorbed at different potentials. Between 50 and $400 \mathrm{mV}$ there is no dependence of the profiles on the potential at which $\mathrm{CO}$ was adsorbed. This is because at these potentials the $\mathrm{CO}$ is not oxidized on $\mathrm{Pt}$, which needs the participation of adsorbed $\mathrm{OH}$ species formed at potentials above $0.7 \mathrm{~V}$ vs. RHE. Figure 7 shows the same experiment with Pt-Ru/C (50:50 E-TEK). In this case, the charge due to $\mathrm{CO}$ oxidation decreases slightly

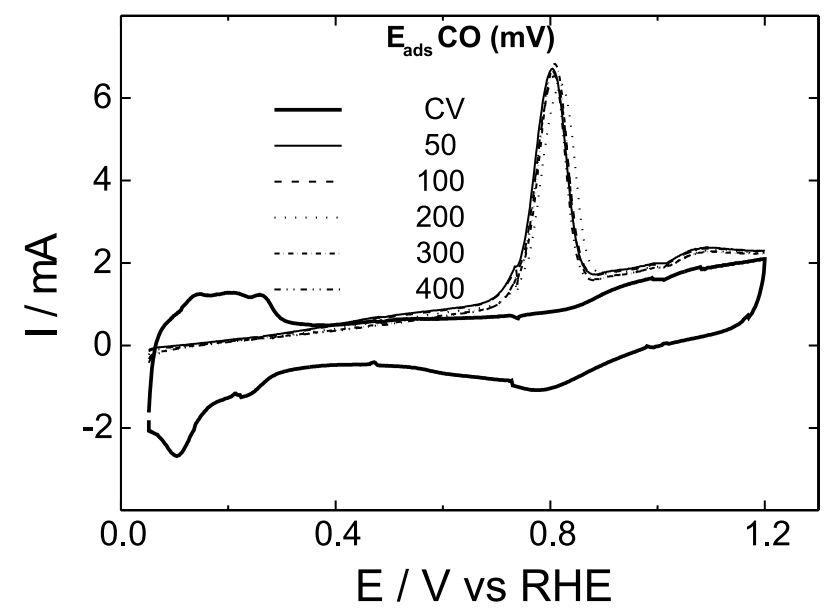

Figure 6. Stripping curves for $\mathrm{CO}$ oxidation on $\mathrm{Pt} / \mathrm{C}$ E-TEK with adsorption of $\mathrm{CO}$ at several potential values indicated in the Figure in $\mathrm{mV}$. $\mathrm{v}=10 \mathrm{mV} \mathrm{s}^{-1}$. A cyclic voltammogram without $\mathrm{CO}$ is also included. for increasing values of the $\mathrm{CO}$ adsorption potential. This is due to the oxidation of $\mathrm{CO}$ to $\mathrm{CO}_{2}$ at potentials over 200 $\mathrm{mV}$, induced by oxygenated species formed on $\mathrm{Ru}$, and the extent of oxidation increases for increasing potentials. Because of this effect, all experiments were done adsorbing $\mathrm{CO}$ at $50 \mathrm{mV}$.

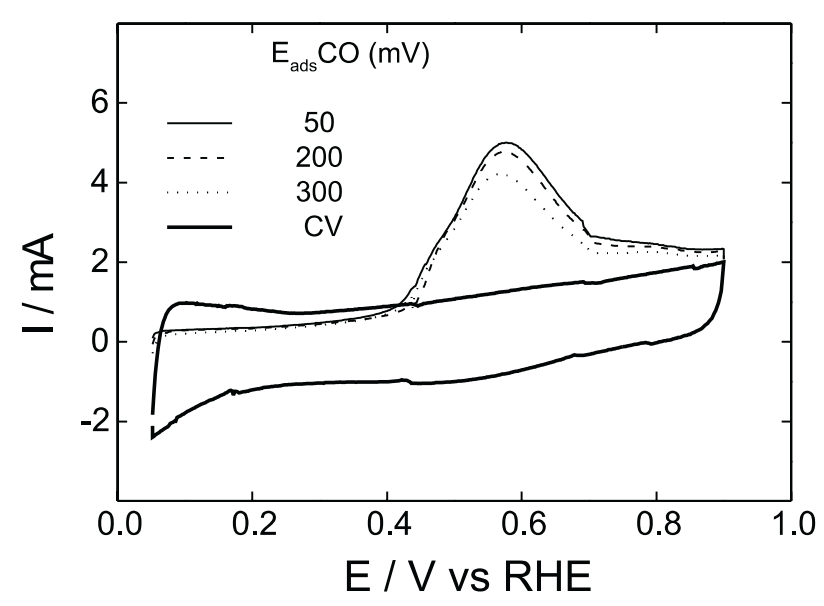

Figure 7. Stripping curves for $\mathrm{CO}$ oxidation on Pt-Ru/C 50:50 ETEK with adsorption of $\mathrm{CO}$ at several potential values. $\mathrm{v}=10 \mathrm{mV} \mathrm{s}^{-1}$. A cyclic voltammogram without $\mathrm{CO}$ is also included.

The stripping of $\mathrm{CO}$ on Pt presents an oxidation peak at a potential that depends on several factors. On the Pt/C electrodes used in this work, the peak potential is $0.815 \mathrm{~V}$ at $10 \mathrm{mV} \mathrm{s}^{-1}$, which is much more positive than the value of $0.73 \mathrm{~V}$ observed on smooth $\mathrm{Pt}^{9}$ and platinized $\mathrm{Pt}^{52}$ Schmidt et $a .^{30}$ found a peak potential of $0.81 \mathrm{~V}$ at $20 \mathrm{mV} \mathrm{s}^{-1}$ on a thin supported catalyst electrode covered with Nafion ${ }^{\circledR}$, with no influence of diffusional effects, which agrees with the value of $0.80 \mathrm{~V}$ found on $\mathrm{Pt}$ (111) by the same authors. For scan rates of $50 \mathrm{mV} \mathrm{s}^{-1}$ other authors found a peak potential of $0.87 \mathrm{~V} .{ }^{53}$ As discussed by Schmidt et al..$^{30}$ the oxidation peak potential of $\mathrm{CO}$ on $\mathrm{Pt}$ nanoparticles appears around $0.81 \mathrm{~V}$ due to the fact that in small particles there is a predominance of (111) facets on the surface. ${ }^{40,54}$

Figure 8A shows linear sweep voltammetry curves for the oxidation of $\mathrm{CO}$ on the Pt-Ru/C 80:20 catalysts prepared by the FAM and 50:50 prepared by the Radmilovic method. Also, the curves for the commercial catalysts $\mathrm{Pt} / \mathrm{C}$ and Pt-Ru/C 50:50 E-TEK are shown. Neglecting double layer charging contributions, no currents are observed up to $0.2 \mathrm{~V}$. On Pt/C a pre-wave can be observed between 0.20 and $0.75 \mathrm{~V}$. This pre-wave was attributed to the oxidation of weakly adsorbed $\mathrm{CO},{ }^{55}$ and it can also be seen up to $0.5 \mathrm{~V}$ on Pt-Ru/C materials (Figure $8 \mathrm{~A}$ ). Between 0.4 and $0.63 \mathrm{~V}$ the most active electrocatalyst is the commercial material Pt-Ru/C 50:50 E-TEK. Between 0.5 and $0.63 \mathrm{~V}$ the Pt-Ru/C 80:20 prepared by the FAM 
and submitted to thermal treatment and the material prepared by the Radmilovic method present similar activity for the oxidation of $\mathrm{CO}$. In spite of the improvement of the FAM material due to the thermal treatment the performance is not as good as that of the commercial E-TEK catalysts. Although a strict comparison cannot be made due to the differences in Ru content, it is probable that the better performance of the commercial material is due to a smaller particle size and a better $\mathrm{Ru}$ distribution on the surface of the electrocatalyst.

Figure 8B shows linear sweep voltammograms for the oxidation of $\mathrm{CO}$ on $\mathrm{Pt}-\mathrm{Ru} / \mathrm{C}$ 80:20 materials in which one of the metals was anchored first (Pt-Ru/C or Ru-Pt/C). It also shows the effect of the thermal treatment on these materials. The materials show some evidences of inhomogeneity. For example, in the material where $\mathrm{Ru}$ was anchored first, the peak at $0.5 \mathrm{~V}$ may be characteristic of $\mathrm{CO}$ oxidation on $\mathrm{Ru}$ particles. ${ }^{9}$ Without a thermal treatment, the alloy in which Pt was anchored first shows the best performance. That of the $\mathrm{Ru}-\mathrm{Pt} / \mathrm{C}$ material is poor, as is that of the material with simultaneous anchoring (Figure 8A). Evidently, the thermal treatment introduces qualitative changes in the performance

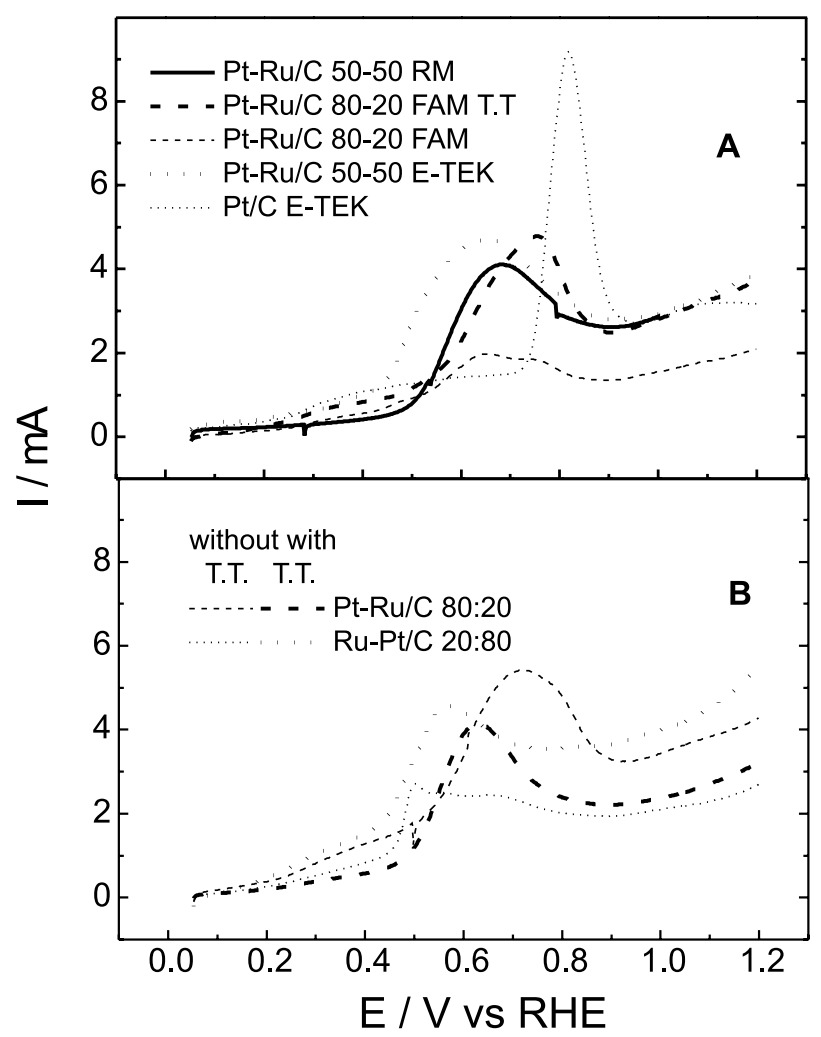

Figure 8. (A) Stripping curves of $\mathrm{CO}$ on Pt-Ru/C electrocatalysts, prepared by different methods, and E-TEK materials. Adsorption of $\mathrm{CO}$ at $50 \mathrm{mV}$ vs RHE. $\mathrm{v}=10 \mathrm{mV} \mathrm{s}^{-1}$. T. T.: thermal treatment. (B) Stripping curves of $\mathrm{CO}$ on Pt-Ru/C FAM electrocatalysts anchored in succession (with the order indicated in the material). Adsorption of $\mathrm{CO}$ at $50 \mathrm{mV}$ vs RHE. $\mathrm{v}=10 \mathrm{mV} \mathrm{s}^{-1}$. T.T.: thermal treatment. of the electrocatalysts for the oxidation of $\mathrm{CO}$. The performance of the $\mathrm{Ru}-\mathrm{Pt} / \mathrm{C}$ material and that of the material with simultaneous anchoring show a marked improvement, while that of the Pt-Ru/C materials decreases somewhat. This is mainly the result of the combined effects of segregation of the materials and the increase in particle size due to sintering and agglomeration. The conclusion is that the $\mathrm{Ru}-\mathrm{Pt} / \mathrm{C}$ material with thermal treatment presents the lower potential for the oxidation of $\mathrm{CO}$ and currents comparable with those of the other materials.

The charge associated to the oxidation of $\mathrm{CO}$, corrected for the double layer charging, was used to calculate the active areas of the catalysts and the values are presented in Table 2. The catalysts prepared by the FAM present an active area similar to that of $\mathrm{Pt} / \mathrm{C}$ E-TEK, which is smaller than that of Pt-Ru/C E-TEK, probably due to the smaller particle size for this last material. For the catalysts prepared by the FAM, the thermal treatment promotes an increase in the active area, particularly for the material where the two metals were anchored simultaneously. This material without the thermal treatment presents active areas similar to those reported by Takasu et al. ${ }^{48}$ who found active areas of $34 \mathrm{~m}^{2} \mathrm{~g}^{-1}$ for $\mathrm{Pt}-\mathrm{Ru} / \mathrm{C}$ materials prepared by impregnation using $\mathrm{RuCl}_{3}$ as precursor.

Table 2. Electroactive areas of the different materials prepared by the FAM determined through the charge to oxidise a monolayer of CO. T.T.: thermally treated materials. The areas were normalized per $\mathrm{g}$ of Pt for all the catalysts

\begin{tabular}{cc}
\hline Catalysts & Electroactive area $\left(\mathrm{m}^{2} \mathrm{~g}_{(\mathrm{Pt})}^{-1}\right)$ \\
\hline Pt-Ru/C $(\mathrm{s})$ & 33.5 \\
Pt-Ru/C $(\mathrm{s})$ T.T. & 58.0 \\
Ru-Pt/C & 31.5 \\
Ru-Pt/C T.T. & 44.6 \\
Pt-Ru/C & 45.3 \\
Pt-Ru/C T.T. & 48.4 \\
Pt-Ru/C 50:50 E-TEK & 66.5 \\
Pt/C 100 E-TEK & 56.0 \\
\hline
\end{tabular}

(s): simultaneously anchoring of Pt and Ru; T. T.: Thermal treatment; ${ }^{a} \mathrm{Ru}$ anchored first; ${ }^{\mathrm{b}} \mathrm{Pt}$ anchored first.

\section{Experiments in single PEMFC}

In order to extrapolate the results obtained with the TPC/RDE to practical systems, experiments were carried out in single PEMFC using Pt-Ru/C 80:20 catalysts prepared by the FAM. Figure 9 shows the performance of single cells operating with pure $\mathrm{H}_{2}$ and with $\mathrm{H}_{2}$ containing $100 \mathrm{ppm}$ CO. The catalysts used in the gas diffusion electrodes were all thermally treated for $1 \mathrm{~h}$ in a $\mathrm{H}_{2}$ atmosphere at $300{ }^{\circ} \mathrm{C}$. For comparison, Figure 9 incorporates results obtained with $\mathrm{Pt} / \mathrm{C}$ and $\mathrm{Pt}-\mathrm{Ru} / \mathrm{C} \mathrm{E}-$ TEK. 


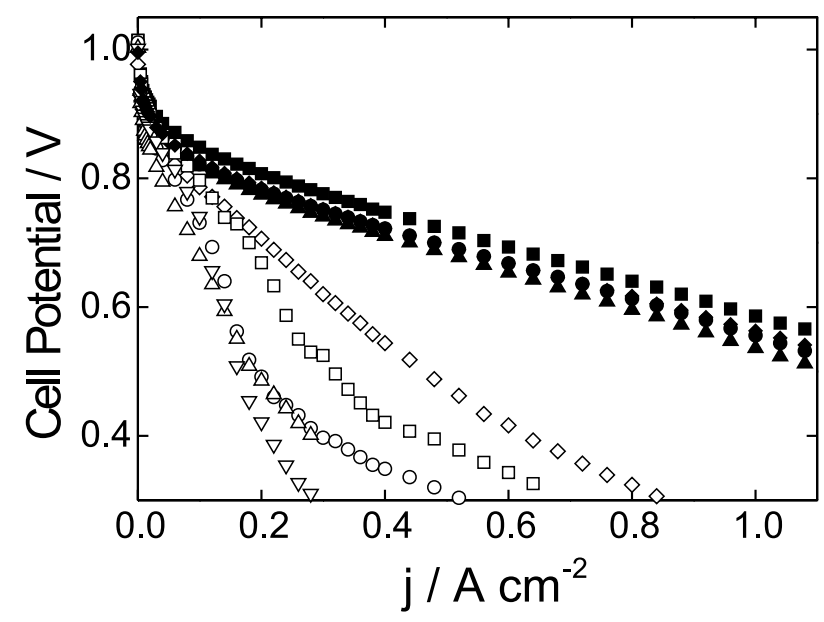

Figure 9. Curves $\mathrm{E}$ vs $\mathrm{J}$ in a single PEMFC operating with hydrogen (full symbols) or $\mathrm{H}_{2} / 100 \mathrm{ppm} \mathrm{CO}$ (open symbols) using several electrocatalysts. (square) Pt-Ru (s) 80:20, (diamond) Pt-Ru/C 50:50 E-TEK, (circle) Pt-Ru/C 80:20, (up triangle) Ru-Pt/C 20:80 and (down triangle) Pt/C E-TEK.

When pure $\mathrm{H}_{2}$ is used, the best results are obtained with catalysts in which Pt and Ru were incorporated simultaneously. The little differences in electrochemical performance for the different electrocatalysts can be associated to experimental errors because the oxidation of $\mathrm{H}_{2}$ on $\mathrm{Pt}$ is very fast $\left(\mathrm{i}_{\mathrm{o}}=3.16 \mathrm{~mA} \mathrm{~cm}-2\right.$ at $\left.\mathrm{pH}=0\right)$.

When $\mathrm{H}_{2}$ with 100 ppm $\mathrm{CO}$ is used in the anode there is, as expected, a large loss in performance for $\mathrm{Pt} / \mathrm{C}$. On the other hand, for $\mathrm{Pt}-\mathrm{Ru} / \mathrm{C}$ the loss is not so pronounced. In the region of low cd the losses are smaller probably due to the oxidation of weakly adsorbed CO. Again, the Pt-Ru/C material in which the metals were anchored simultaneously shows a better performance due to a smaller particle size and a larger active area as it was demonstrated by the calculation done from the charge necessary to oxidize a monolayer of CO. The thermal treatment affects the distribution of $\mathrm{Ru}$ and probably the material with simultaneous anchoring of $\mathrm{Pt}$ and $\mathrm{Ru}$ presents a better geometry at the molecular level for a bifunctional mechanism. When the two metals were incorporated separately, it makes no difference which metal is anchored first for the resulting active area (Table 2). For these materials, the increase in the active area with the thermal treatment is most probably due to a cleaning process of the catalysts as a consequence of the thermal treatment and possibly to a better distribution of $\mathrm{Ru}$. The potential drop with current is lower for the 50:50 E-TEK Pt-Ru/C catalysts. A proper comparison with the FAM catalyst prepared here cannot be made because these present lower $\mathrm{Ru}$ contents and larger particle sizes. These results seem to confirm that for the oxidation of $\mathrm{CO}$ the best composition of the Pt-Ru alloy is 50:50.56

\section{Conclusions}

The TPC/RDE showed to be suitable for the experimental evaluation of carbon supported catalysts and for studies of the mechanism of the reaction. With this technique it was possible to evaluate $\mathrm{Pt}-\mathrm{Ru} / \mathrm{C}$ catalysts prepared by different methods and submitted to different treatments for the oxidation of CO. Although the TPC/RDE technique showed differences in the results when one of the metals is anchored first, the results in single PEMFC were better for catalysts in which the two metals were incorporated simultaneously. A proper comparison of the materials prepared here with the commercial E-TEK catalysts could not be made because of the lower $\mathrm{Ru}$ content of the former.

\section{Acknowledgements}

Thanks are due to FAPESP, CNPq and FINEP (PRONEX), Brazil, for financial support. F.C.J. and W.H.L.V. thank FAPESP for research scholarships (98/ 10947-3 and 98/12922-8, respectively). The authors thank Vania Cardoso and Carlos Bento for the DRX and EDX experiments, respectively.

\section{References}

1. Du Melle, F. J.; J. Power Sources 1998, 71, 7.

2. Kordesch, K.; Simader, G.; Fuel Cells and their Applications, VCH: Weinheim, 1996.

3. Emonts, B.; Bogild Hansen, J.; Loegsgaard Jorgensen, S.; Hohlein, B.; Peters, R.; J. Power Sources 1998, 71, 288.

4. Twigg, M. V.; Catalysts Handbook, Frome: Manson, 1996.

5. Hamnett, A. In Interfacial Electrochemistry. Theory, Experiment and Applications; Wieckowski, A.; ed.; Marcel Dekker, Inc.: New York, 1998.

6. Gottesfeld, S.; Pafford, J.; J. Electrochem. Soc. 1998, 135, 2651.

7. Gang, X.; Qinfeng, L.; Hjuler, H. A.; Bjerrum, N. J.; J. Electrochem. Soc. 1995, 142, 2890.

8. Teng, Y.; Sakurai, H.; Ueda, A.; Kobayashi, T.; Int. J. Hydrogen Energy 1999, 24, 355.

9. Gasteiger, H. A.; Markovic, N. M.; Ross, P. N.; J. Phys. Chem. 1995, 99, 8290.

10. Gasteiger, H. A.; Markovic, N. M.; Ross, P. N.; J. Phys. Chem. 1995, 99, 16757.

11. Gasteiger, H. A.; Markovic, N. M.; Ross, P. N.; Cairns, E. J.; J. Phys. Chem. 1994, 98, 617.

12. Morimoto, Y.; Yeager, E. B.; J. Electroanal. Chem., 1998, $441,77$.

13. Oetjen, H. -F.; Schmidt, V. M.; Stimming, U.; Trila, F.; J. Electrochem. Soc. 1996, 143, 3838. 
14. Shibata, M.; Furuya, N.; J. Electroanal. Chem. 1989, 274 245.

15. Ross, P. N.; Kinoshita , K.; Scarpellino, A. J.; Stonehart, P.; J. Electroanal. Chem. 1975, 59, 177.

16. Grgur, B. N.; Zhuang, G.; Markovic, N. M.; Ross Jr, P. N.; J. Phys. Chem. B. 1997, 101, 3910.

17. Grgur, B. N.; Markovic, N. M.; Ross, P. N.; Electrochim. Acta 1998, 43, 3631 .

18. Schmidt, T. J.; Gasteiger, H. A.; Behm, R. J.; Abstract of the Workshop Electrocatalysis in Indirect and Direct Methanol PEM Fuel Cells. IIIrd International Symposium in Electrocatalysis, Portoroz, Slovenia, 1999.

19. Schmidt, V. M.; Oetjen, H. F.; Divisek, J.; J. Electrochem. Soc. 1997, 144, L237.

20. Divisek, J.; Oetjen, H. -F.; Peinecke, V.; Schmidt, V. M.; Stimming, U.; Electrochim. Acta 1998, 43, 3811.

21. Mukerjee, S.; Lee, S. J.; Ticianelli, E. A.; McBreen, J.; Grgur, B. N.; Markovic, N. M.; Ross, P. N.; Giallombardo, J. R.; De Castro, E. S.; Electrochem. Solid-State Lett. 1999, $2,12$.

22. Watanabe, M.; Motoo, S.; J. Electroanal. Chem. 1975, 60 275 .

23. Iwasita, T.; Nart, F. C.; In Advances in Electrochemical Science and Engineering; Gerischer, H.; Tobias, C., eds.; VCH: Weinheim, 1995.

24. Wolter, O.; Heitbaum, J.; Ber Bunsenges. Phys. Chem. 1984, $88,6$.

25. Watanabe, M.; Motoo, S.; J. Electroanal. Chem. 1986, 206, 197.

26. Chang, S-C.; Weaver, M. J.; J. Chem. Phys. 1990, 92, 4582.

27. Morimoto, Y.; Yeager, E. B.; J. Electroanal. Chem. 1998, 441 77.

28. Ianniello, R.; Schmidt, V. M.; Stimming, U.; Stumper, J.; Wallau, A.; Electrochim. Acta 1994, 39, 1863.

29. Arico, A. S.; Modica, E.; Passalacqua, E.; Antonucci, V.; Antonucci, P.L.; J. Appl. Electrochem. 1997, 27, 1275.

30. Schmidt, T. J.; Gasteiger, H. A.; Stab, G. D.; Urban, P. M.; Kolb, D. M.; Behm, R. J.; J. Electrochem. Soc. 1998, 145, 2354.

31. Schmidt, T. J.; Gasteiger, H. A.; Behm, R. J.; J. Electrochem. Soc. 1999, 146, 1296.

32. Castro Luna, A. M.; Camara, G. A.; Paganin, V. A.; Ticianelli, E. A.; Gonzalez, E. R.; Electrochem. Commun. 2000, 2, 222.

33. Tanaka, A. A.; Fierro, C.; Scherson, D.; Yeager, E. B.; J. Phys. Chem. 1987, 91, 3799.

34. Perez, J.; Tanaka, A. A.; Gonzalez, E. R.; Ticianelli, E.A.; J. Electrochem. Soc. 1994, 141, 431.

35. Calegaro, M. L.; Perez, J.; Tanaka, A. A.; Ticianelli, E. A.; Gonzalez, E. R.; Denki Kagaku 1996, 64, 436.

36. Martins, S. A. M.; Perez, J.; Torresi, R. M.; Luengo, C. A.; Ticianelli, E. A.; Electrochim. Acta. 1999, 44, 3565.
37. Oliveira Neto, A.; Perez, J.; Napporn, W. T.; Ticianelli, E. A.; Gonzalez, E. R.; Abstract of the Workshop Electrocatalysis in Indirect and Direct Methanol PEM Fuel Cells. IIIrd International Symposium in Electrocatalysis, Portoroz, Slovenia, 1999.

38. Pinheiro, A L. N.; Oliveira Neto, A.; De Souza, E. C.; Perez, J.; Paganin, V. A.; Ticianelli, E. A.; Gonzalez, E. R.; Abstract of the 2000 Fuel Cell Seminar, Portland, USA, 2000.

39. Gonzalez, E. R.; Ticianelli, E. A.; Pinheiro A. L. N.; Perez, J., Br INPI 00321, 1997

40. Radmilovic, V.; Gasteiger, H. A.; Ross, P. N.; J. Catal. 1995, $154,98$.

41. Watanabe, M.; Uchida, M.; Motoo, S.; J. Electroanal. Chem. 1987, 229, 395.

42. Joint Committee on Powder Diffraction Standards, Powder Diffraction File, U. S. A., card 4-802

43. Cullity, B. D.; Elements of X-Rays Diffraction, Addison-Wesley: Reading, 1978.

44. Hammond, C.; Introduction to Crystallography, Oxford University: Oxford, 1990.

45. West, A. R.; Solid State Chemistry and its applications, John Wiley \& Sons: New York, 1984.

46. Arico, A. S.; Creti, P.; Kim, H.; Mantegna, R.; Giordano, N.; Antonucci, V. J.; J. Electrochem. Soc. 1996, 143, 3950.

47. Gurau, B.; Viswanathan, R.; Liu, R.; Lafrenz, T. J.; Ley, K. L.; Smotkin, E. S.; Reddington, E.; Sapienza, A.; Chan, B. C.; Mallouk, T. E.; Sarangapani, S.; J. Phys. Chem. B. 1998, 102 , 9997.

48. Takasu, Y.; Fujiwara, T.; Murakami, Y.; Sasaki, K.; Oguri, M.; Asaki, T.; Sugimoto, W.; J. Electrochem. Soc. 2000, 147, 4421 .

49. Seddon, E. A.; Seddon, K. R.; The Chemistry of Ruthenium, Elsevier: New York, 1984.

50. Ticianelli, E. A.; Beery, J. G.; Paffet, M. T.; Gottesfeld, S.; J. Electroanal. Chem. 1989, 258, 61.

51. Frelink, T.; Visscher W.; van Veen, J. A. R.; J. Electroanal. Chem. 1995, 382, 65.

52. Iúdice de Souza, J. P.; Iwasita, T.; Nart, F. C.; Vielstich, W.; J. Appl. Electrochem. 2000, 30, 43.

53. Feliu, J. M.; Orts, J. M.; Fernandez-Vega, A.; Aldaz, A.; J. Electroanal. Chem. 1990, 296, 191.

54. Stonehart, P.; J. Appl. Electrochem. 1992, 22, 995.

55. Herrero, E.; Feliu, J. M.; Aldaz, A.; J. Electroanal. Chem. 1996, 368, 101 .

56. Gasteiger, H. A.; Markovic, N. M.; Ross, P. N.; Cairns, E. J.; J. Phys. Chem. 1993, 97, 12020.

Received: January 18, 2002 Published on the web: July 16, 2002

FAPESP helped in meeting the publication costs of this article. 